\author{
Kinga Krzesiwo \\ Kamila Ziółkowska-Weiss \\ Michał Żemła \\ Pedagogical University of Cracow \\ Faculty of Geography and Biology \\ Institute of Geography \\ krzesiwo@up.krakow.pl \\ kamilacamela@up.krakow.pl \\ michalzemla@up.krakow.pl
}

\title{
THE ATTRACTIVENESS OF SELECTED CENTRAL EUROPEAN COUNTRIES FOR WINTER SPORTS AND MOUNTAIN HIKING
}

\begin{abstract}
Hiking, downhill skiing and snowboarding are among the most popular forms of active tourism in mountainous areas. Their popularity and their mass scale do not only result from the presence of the appropriate landscape, but also from its appropriate development. The objective of the article is to attempt to assess the attractiveness of selected Central European countries in terms of winter sports and mountain hiking, to consider the opinions of students who live in Visegrad Group countries, as well as to evaluate the barriers to development of their competitive offers. According to respondents, the most attractive countries for winter sports are Austria and Slovakia, and the least attractive are Hungary, Romania and Lithuania. In turn, according to the students, the best conditions for mountain hiking are in Slovakia, Austria, the Czech Republic and Poland. In addition, respondents from particular countries assessed domestic offers highly.
\end{abstract}

Keywords: tourist attractiveness, winter sports, mountain hiking, Central Europe.

\section{INTRODUCTION}

Recreation can be understood as a set of an individual's activities and behaviours in leisure time. Recreation is commonly divided into active and passive (LUBOWIECKIVIKUK \& PACZYŃSKA-JĘDRYCKA 2010). According to another popular classification, recreation is divided into physical, creative, cultural and entertainment-oriented, as well as recreation through social activity (KIEŁBASIEWICZDROZDOWSKA 2001, p. 16). Physical recreation includes numerous activities such as cycling, skiing, hiking, water sports or dancing. Active tourism constitutes a concept closely related to physical recreation, understood as a form of tourism in which the main or important element is - regardless of its duration - undertaking a particular type of recreation or hobby (ANDREJUK 1998) $)^{1}$. It includes both traditional forms such as hiking, cycling, canoeing, but also newer ones, e.g. canyoning or geocaching. It is worth noticing that the majority of these are undertaken outdoors, both in leisure time at home or away from home during tourist trips. What is more, some of these activities require a specific natural environment. This mainly concerns hiking and skiing, primarily in mountain areas, as well as water sports on natural or artificial lakes and watercourses. Mountain hiking and winter sports, mainly downhill skiing and snowboarding, constitute the most popular forms of active tourism. As a result, without denying the importance and popularity of other forms of active tourism in mountainous areas, the analysis here will be limited to these two forms. Their popularity and global scale result not only from the presence of suitable natural conditions, but also (primarily in the case of winter sports) from the appropriate use of these assets. On the other hand, economic bodies which provide services for hiking and/or winter sports see them as the target market prepared so that it could attract as many customers as possible. The effectiveness of supply increases choice as well as expectations regarding the quality of the offered product on the demand side. In this way, the market is becoming more and more competitive, and the competition between companies and places to attract tourists for hiking and/or winter sports, gains not only a local and regional character, but also national or even international. 


\section{OBJECTIVES AND RESEARCH METHODOLOGY}

The objective of the article is to attempt to assess the attractiveness of selected Central European countries in terms of winter sports and mountain hiking, to consider the opinions of students who live in Visegrad Group countries related, as well as to evaluate the barriers to development of their competitive offers. To accomplish this goal, a critical analysis of the literature has allowed the identification of the main developmental barriers to mountain hiking and winter sports in Poland, the Czech Republic and Slovakia was made and survey research was carried out. The survey questionnaire was placed on the internet in the first half of 2016. It was addressed to students in disciplines related to tourism in the countries belonging to the Visegrad Group. The survey involved 195 people: 78 from Slovakia, 46 from the Czech Republic, 43 from Poland and 28 from Hungary. The research took place through cooperation between lecturers from various universities who provided students with a link to the questionnaire which was then disseminated using the so-called snowball sampling method.

The subject of the respondents' evaluations was the attractiveness of the offer of nine Central European countries: Austria, Lithuania, Germany, Poland, the Czech Republic, Romania, Slovakia, Slovenia and Hungary ${ }^{2}$ in terms of winter sports and mountain hiking. The respondents were asked to indicate (at most) five countries which - in their opinion - are the most attractive taking into account the above-mentioned forms of active tourism.

\section{SELECTED CONTEMPORARY DIRECTIONS OF AND BARRIERS TO THE DEVELOPMENT OF WINTER SPORTS RESORTS ${ }^{3}$ AND MOUNTAIN HIKING CENTRES IN POLAND}

The development of winter sports areas is an important factor of economic and population growth, as well as a substantial source of employment and income for local communities; it also contributes to a better quality of socio-technical infrastructure at mountain destinations (KuREK 2004, LindBERG, ANDERSSON, DELlAERT 2001). However, apart from the economic and social benefits, the development of infrastructure needed brings many harmful ecological effects mostly as a result of building a skiing infrastructure, as well as the fact that large numbers of people stay in a relatively small area at the same time (HOLDEN 2000, HUDSON 2000, KUREK 2004,
TSUYUZAKI 2002). Moreover, researchers often discuss the influence of climatic change on the functioning of winter sports resorts (FALK 2010, TÖGLHOFER 2011), seasonality (HERBIN 1995, TUPPEN 2002), as well as the decreasing demand of major mature European markets (TUPPEN 2002, HUDSON \& HUDSON 2015).

Considerably less attention has been paid in recent years to mountain hiking. In this case, academic research usually concentrates on the influence of this activity on the natural environment (GENELETTI \& DAWA 2009, FIDELUS 2016, FIDELUS-ORZECHOWSKA et al. 2017), while the economic and/or organizational aspects are discussed more rarely (SZCZECHOWICZ 2006, ZARZYCKI et al. 2006, ŻEMŁA 2015).

An increase in numbers skiing or snowboarding, a higher frequency of trips and a significant increase in the requirements regarding the quality of the services provided has led to an unprecedented investment boom in Polish ski resorts, which has been observed since the beginning of the $21^{\text {st }}$ century

In Poland, the increasing number of mountain hikers, as well as clearly growing expectations, have led to unprecedented investment in Polish ski resorts. Over this period, the number of modern and comfortable ski lifts in Polish resorts has multiplied. Traditional ski centres are gradually being modernized, new resorts are being opened; both smaller, family-type, and larger ones, offering more varied descents. The rising quality of service at Polish ski resorts can be seen in the fact that a large majority of pistes have been equipped with snowmaking systems, and many of them have been illuminated. The increase in tourism at Polish ski destinations and their rapid development also generates numerous conflicts, which are the source of difficulties in their development and functioning. In the Polish academic literature, this issue has been discussed by, for example, M. MiKA et al. (2007), K. KRZESIWO (2007, 2014), M. MIKA (2009).

According to research conducted among those who manage ski resorts by KRZESIWO (2014) the most significant problem for investors as regards the skiing infrastructure in Poland is the legal aspect concerning environmental protection. It is indicated that the law regulating it makes the procedural-administrative process extremely complicated and burdensome for investors. Another important problem is the lack of law regulating the relations between land owners and investors in the skiing infrastructure. The lack of agreement concerning the financial conditions of leased land results in the closure of ski lifts and pistes. These conflicts are more visible at traditional ski stations such as Piwniczna Zdrój, Szczyrk, Zakopane and Zwardoń.

Due to advancing climatic change, as a result of which the presence of snow is not certain and weather conditions are unstable, ski resorts are forced to adapt to new conditions. The most popular strategy is using 
devices for snow production. Snowmaking requires a large supply of water, but not every ski resort has free access to natural resources. A major problem in the development and functioning of ski resorts in Poland is the insufficient volume of water which must be used for producing artificial snow. Intensive snowmaking also has a substantial influence on the profitability of individual resorts.

The possibility of quick and convenient access to a destination constitutes one of the most important elements of tourist attractiveness, as well as the efficiency of the internal transport system. Significant drawbacks at some ski stations include frequent road congestion, access roads to ski resorts being too narrow and poor in quality, an insufficient number of parking places and ineffective snow removal.

In recent years, an important aspect of winter sports development has been the cooperation among ski resort investors, which has been developing between neighbouring countries (Czech Republic, Slovakia) for a long time. It results in effective industry classification and efficient information systems on the internet.

In contrast to winter sports, numbers mountain hiking have not changed significantly in recent years (PILAWSKI 2002, ŻEMŁA 2015). The number of marked trails and shelters, which is an important element of tourist development of mountain areas, has not increased, either. This fact, as well as the character of the activity itself, which does not require a complicated technical infrastructure, makes it difficult to indicate recent major investments. However, most cable car lines originally built for tourists to use in winter are also available in the summer season to hikers and sometimes mountain bikers. This significantly improves the accessibility of many attractive mountain areas.

\section{SELECTED BARRIERS TO THE DEVELOPMENT OF WINTER SPORTS RESORTS AND MOUNTAIN TOURISM CENTRES IN SLOVAKIA AND THE CZECH REPUBLIC}

In the Czech Republic and Slovakia, the winter sports industry - as compared to Poland - has reached a mature stage and it is currently obliged to maintain a continuously high level of demand. The most important barriers to the development and functioning of ski resorts in Slovakia include the following (MADZIKOVA et al. 2011):

- legal issues related to environmental protection,

- shortage of funds for modernizing skiing infrastructure,
- lack of legal regulations concerning the way and extent to which land is made accessible to skiers between land owners and ski resort administrators,

- a decreasing popularity of skiing in Slovakia among foreign tourists.

Large investment projects connected with the development of Slovakian ski resorts are in some cases endangered due to legal restrictions related to environmental protection. Many ski resorts in Slovakia are situated on territories included in the international network, Nature 2000 (MADZIKOVA et al. 2011).

In order to adapt to the changing climatic conditions and to increase tourist attractiveness, skiing infrastructure investors are forced to improve the quality of the services they provide by building snowmaking systems and modernizing the existing devices transporting the skiers up the ski slopes. Particular ski resorts, especially those located by mountain hotels, do not have the financial and organizational resources to carry out such investments. Due to this, more and more small ski resorts in Slovakia are going bankrupt.

The most serious problem connected with the development and functioning of ski resorts in Poland, the Czech Republic and Slovakia are the legal barriers related to environmental protection policy (HAVRLANT 2011). In many cases, representatives of ecological organizations obstruct even those undertakings which aim at improving the organization of recreational areas, transformed earlier.

In the mountain areas of the Czech Republic, there is the problem of land property status. These conflicts, however, are not as acute as in the Polish part of the Carpathians (cf. KRZESIWO 2014, MIKA et al. 2007). Conflicts concerning ownership arise, for example, at the stage of planning the modernization of ski resorts. Due to the lack of regulations concerning ownership, the development of the Jaworowy Wierch (1013 m above sea level) ski resort had to be stopped.

An interesting issue is the significant difference in how mountain hiking is developing in the Czech Republic, Slovakia and Poland (SzCZECHOwICZ 2014, ŻEMEA 2015). While the popularity of this form of recreation is similar in these countries, the ways of developing mountain areas are visibly different, both as regards establishing the tourist trails and the functioning of mountain shelters. The differences concerning the trails are rather insignificant - in the Czech Republic, the length of trails is specified in kilometres, while in Poland and Slovakia, in hours of walking. More significant is the different number of shelters, their ownership status, standard and availability. A considerably smaller number of shelters are located in Slovakia; they are mostly typically high-mountain facilities, with basic furnishings, very difficult to access, where food provisions have to be delivered. Most shelters are 
situated in the most attractive mountain ranges (Tatras, Fatras), while in other mountain areas there are often no shelters at all. It is quite the opposite in the Czech Republic where there are many shelters, they are relatively evenly distributed in all mountain ranges; they are usually high standard mountain hotels, accessible not only to delivery vehicles, but also to hotel guests. In contrast to Poland and Slovakia, where the majority of shelters are run by tourism associations and clubs (PTTK - Polish Tourism Association, and KST), most Czech facilities are private property. In Poland, mountain shelters are numerous and evenly distributed. They can usually be reached by off-road delivery car. They are of basic standard and they are mostly the property of PTTK. Quite typically, the inhabitants of all three countries prefer mountain hiking as a form of domestic tourism (ŻEMŁA 2014, ŻEMŁA 2015).

\section{ASSESSMENT OF ATTRACTIVENESS OF THE OFFER IN THE OPINION OF STUDENTS}

The ability to attract guests constitutes an element that significantly influences the current and future competitive position of particular destinations. The percentage of responses regarding the most attractive countries in terms of winter sports is presented in Table 1.
According to the respondents, Austria and Slovakia are definitely the most attractive countries for winter sports (Table 1). Such responses were provided by respondents from all the surveyed countries. The following positions were taken by Germany, the Czech Republic, Slovenia and Poland. The smallest number concerned Hungary, Romania and Lithuania, which means that they are considered by respondents to be less attractive for winter sports. It is noteworthy that respondents from individual countries highly evaluated their domestic offer and the many respondents from Slovakia and the Czech Republic could have had an effect on the high rating of these countries. When analyzing the answers of respondents from individual countries, it is clear that the geographical proximity of individual states can be a significant factor influencing the results. Germany was indicated by a large number of respondents from the Czech Republic, while it was not chosen by respondents from Poland. A small number of Slovaks have a similar opinion about Hungary, claiming that this country is not attractive for winter sports fans.

In the next part of the study, the respondents were asked to indicate countries, also a maximum of five, which they believed were most attractive for summer mountain hiking. Indications in response to this question are presented in Table 2.

The results show that Czechs pointed to Austria as the best country for mountain hiking. Similar to the previous question, the respondents often indicated

Table 1. Indications by respondents from Poland, the Czech Republic, Slovakia and Hungary, concerning the most attractive, in their opinion, countries with respect to winter sports (by percentage)

\begin{tabular}{|c|c|c|c|c|c|c|c|c|c|}
\hline \multirow[b]{2}{*}{$\begin{array}{c}\text { Respondents' } \\
\text { nationality }\end{array}$} & \multicolumn{9}{|c|}{ Countries indicated by respondents (\%) } \\
\hline & Austria & Lithuania & Germany & Poland & $\begin{array}{c}\text { Czech } \\
\text { Republic }\end{array}$ & Romania & Slovakia & Slovenia & Hungary \\
\hline Poles & 95.3 & 0.0 & 41.9 & 79.1 & 53.5 & 9.3 & 88.4 & 55.8 & 11.6 \\
\hline Czechs & 97.8 & 10.9 & 73.9 & 16.6 & 84.8 & 10.9 & 84.8 & 60.9 & 10.9 \\
\hline Slovaks & 94.9 & 11.5 & 59.0 & 52.6 & 50.0 & 9.0 & 92.3 & 44.9 & 2.6 \\
\hline Hungarians & 92.9 & 21.4 & 57.1 & 50.0 & 39.3 & 10.7 & 64.3 & 50.0 & 10.7 \\
\hline Total & 95.4 & 10.3 & 58.6 & 50.3 & 57.4 & 9.7 & 85.6 & 51.8 & 7.7 \\
\hline
\end{tabular}

Source: authors.

Table 2. Indications by respondents from Poland, the Czech Republic, Slovakia and Hungary concerning the most attractive, in their opinion, countries with respect to mountain hiking (by percentage)

\begin{tabular}{|c|c|c|c|c|c|c|c|c|c|}
\hline \multirow[b]{2}{*}{$\begin{array}{c}\text { Respondents' } \\
\text { nationality }\end{array}$} & \multicolumn{9}{|c|}{ Countries indicated by respondents (\%) } \\
\hline & Austria & Lithuania & Germany & Poland & $\begin{array}{c}\text { Czech } \\
\text { Republic }\end{array}$ & Romania & Slovakia & Slovenia & Hungary \\
\hline Poles & 67.4 & 9.3 & 34.9 & 88.4 & 58.1 & 39.5 & 74.4 & 53.5 & 25.6 \\
\hline Czechs & 89.1 & 17.4 & 41.3 & 26.1 & 82.6 & 32.6 & 78.3 & 63.0 & 21.7 \\
\hline Slovaks & 73.1 & 12.8 & 43.6 & 60.3 & 60.3 & 37.2 & 93.6 & 50.0 & 19.2 \\
\hline Hungarians & 67.9 & 14.3 & 60.7 & 32.1 & 35.7 & 53.6 & 46.3 & 32.1 & 50.0 \\
\hline Total & 74.9 & 13.3 & 43.6 & 54.4 & 61.5 & 39.0 & 79.0 & 51.3 & 25.6 \\
\hline
\end{tabular}

Source: authors. 
the domestic offer, for instance Slovaks clearly believed that Slovakia was the best country for summer mountain walking. Similarly, Poles indicated Poland. The Hungarian respondents' answers may be puzzling, as they consider their country to be a good place for hiking tourism, while those from other countries do not share their enthusiasm, and Hungary together with Lithuania were considered to be the least attractive for this activity. Romania was often indicated by Hungarians, while the respondents from other countries did not rate it very highly.

\section{CONCLUSIONS}

Slovakia is a mountainous country. Areas from 300 to 800 metres above sea level cover about $47 \%$ of its territory, and those over 800 metres - around 13\%. In turn, the Czech Republic is an upland country since areas at altitudes of 300-800 metres occupy as much as $72 \%$ and those over 800 metres $-4 \%$. On the other hand, Poland is a lowland country and areas located at an altitude above 500 metres constitute only 3\% of its territory. Despite this, mountainous areas in Slovakia, the Czech Republic and Poland are the largest and most important tourist regions of these countries (WARSZYŃSKA 1995).

Winter sports and mountain hiking are among the most characteristic forms of recreation in the mountains. Mountain areas in Poland, the Czech Republic and Slovakia are striving at creating a competitive offer in this respect and attracting people for these forms of activity. The relative similarity of natural as well as socio-economic conditions gives the mountain regions in these three countries similar potential and they face similar difficulties. However, the intensity of some problems in individual countries may differ. In Poland, ski resorts are limited above all by matters related to land ownership status and environmental protection. In the Czech Republic and Slovakia, the small national populations seem to be more significant, combined with the problem of international competition, especially with Austria and other Alpine countries. Similar to the winter sports offer, the mountain hiking offer in the three studied countries is built above all with the domestic market in mind. However, differences in expectations on these three markets are also visible in its slightly different organization in Poland, Slovakia and the Czech Republic.

Based on the study, it is possible to show that the development prospects for winter sports and hiking in the Czech Republic, Poland and Slovakia, largely depend on demand trends in these countries. The importance of domestic tourism in the mountain regions of Poland, Slovakia and the Czech Republic is confirmed by the results of the survey presented above. In each case, the offer of a given country obtained inflated ratings among the respondents from that country. On the other hand, the strong position of Slovakia as a place attractive for mountain hiking and winter sports is indisputable. Among the countries included in the study, Slovakia gave way only to Austria as regards winter sports. On the other hand, Poland and the Czech Republic, with results, exceeding $50 \%$ in both rankings, were just behind, however, in both cases assessments of the Czech Republic were significantly higher than the ones related to Poland. However, in both cases, the ratings for the Czech Republic were significantly higher than those for Poland. One of the reasons for this is the very low evaluation of Poland's attractiveness by the Czechs, while Poles evaluated the attractiveness of the Czech Republic definitely higher. Apart from Austria, other major competitors of the countries included in the study are Germany, Slovenia and Romania, the latter only as regards hiking tourism, as its skiing offer was rated surprisingly low.

\section{ENDNOTES}

${ }^{1}$ In the Polish literature, the phrase 'qualified tourism' is difficult to translate into English. A wide discussion of the mutual relationship between the concepts of qualified tourism and active tourism can be found, among others, in the works of A. ANDREJUK (1998), M. ŻEMŁA (2000), J. RUT (2002).

2 The presented results constitute a part of a larger study in which the tourist attractiveness of Central European countries was analyzed, not only in relation to mountainous areas, hence the presence of Lithuania and Hungary in the list.

${ }^{3}$ Polish literature lacks a clear terminology related to skiing, snowboarding and places developed for these purposes. The authors of this article use the term a 'winter sports resort' (HUDSON 2000, TUPPEN 2000, FLAGESTAD \& HOPE 2001, HUDSON \& HUDSON 2015). The terms 'station' and 'centre' with reference to winter sports are used according to the definitions proposed by K. KRZESIWO (2014, p. 21).

\section{BIBLIOGRAPHY}

ANDREJUK A., 1998, Turystyka aktywna, rekreacyjna $i$ specjalistyczna, Kengraf, Warszawa.

DUDEK D., 2006, Pojęcie rekreacji w polskiej tradycji terminologicznej, Folia Touristica, 17, pp. 27-50.

FALK M., 2010, A dynamic panel data analysis of snow depth and winter tourism, Tourism Management, 31, 6, pp. 912-924.

FIDELUS J., 2016, Slope transformations within tourist foot-paths in the northern and southern parts of the Western Tatra Mountains (Poland, Slovakia), Zeitschrift für Geomorphologie, 60 (3), pp. 139-162.

FidELUS-ORZECHOWSKA J., GORCZYCA E., KRZEMIEŃ K., 2017, Geomorfologiczne skutki gospodarki turystycznej w Tatrach, Wyd. IGiGP UJ, Kraków.

FLAGESTAD A., HOPE C. A., 2001, Strategic success in winter sports destinations: a sustainable value creation perspective, Tourism Management, 22 (5), pp. 445-461. 
GENELETTI D., DAWA D., 2009, Environmental impact assessment of mountain tourism in developing regions: A study in Ladakh, Indian Himalaya, Environmental Impact Assessment Review, 29 (4), pp. 229-242.

HAVRLANT J., 2011, Kierunki i bariery modernizacji ośrodków sportów zimowych w czeskim regionie turystycznym 'Beskidy', Prace Geograficzne, 125, pp. 77-93.

HERBIN J., 1995, Mass tourism and problems of tourism planning in French mountains, [in:] G.J. Alshworth, A.G. Dietvorst (eds.), Tourism and spatial transformations, CABI, Wallingford.

HoLDEN A., 2000, Winter tourism and the environment in conflict the case study of Cairngorm, Scotland, International Journal of Tourism Research, 2, 4, pp. 247-260.

HUDSON S., 2000, Snow business. A study of the international ski industry, Cassell, London.

HUDSON S., HUDSON L., 2015, Winter sport tourism, Goodfellow Publishers, Oxford.

KIEŁBASIEWICZ-DROZDOWSKA I., 2001, Zarys rozwoju refleksji teoretycznej nad problematyką rekreacji, [in:] I. KiełbasiewiczDrozdowska, W. Siwiński (eds.), Teoria i metodyka rekreacji, AWF, Poznań, pp. 9-25.

KRZESIWO K., 2007, Turystyka narciarska w Beskidzie Śląskim - stan obecny i problemy rozwoju, [in:] W. Kurek, R. Faracik (eds.), Studia nad turystyka. Prace geograficzne i regionalne. Geograficzne, spoteczne i ekonomiczne aspekty turystyki, Instytut Geografii i Gospodarki Przestrzennej, Uniwersytet Jagielloński, Kraków, pp. 85-97.

KRZESIWO K., 2014, Rozwój i funkcjonowanie stacji narciarskich w polskich Karpatach, Instytut Geografii i Gospodarki Przestrzennej, Uniwersytet Jagielloński, Kraków.

KUREK W., 2004, Turystyka na obszarach górskich Europy, Instytut Geografii i Gospodarki Przestrzennej, Uniwersytet Jagielloński, Kraków.

LINDBERG K., ANDERSSON T.D., DELlAERT B.G.C., 2001, Tourism development: Assessing social gains and losses, Annals of Tourism Research, 28, 4, pp. 1010-1030.

LUBOWIECKI-VIKUK A.P., PASZYŃSKA-JĘDRYCKA M., 2010, Wspótczesne tendencje w rozwoju form rekreacyjnych $i$ turystycznych, AWF, Poznań.

MADZIKOVÁ A., KLAMÁR R., ROSIČ M., KAŇUK J., 2011, Główne kierunki i problemy rozwoju turystyki narciarskiej w Republice Słowackiej, Prace Geograficzne, 125, pp. 111-128.

MIKA M., 2009, Ski tourism in the Polish Carpathians - present state and issues of development, Folia Geographica. Acta Facultatis Studiorum Humanitatis et Naturae Universitatis Presoviensis, 14, pp. 198-208.
MIKA M., KRZESIWO K., KRZESIWO P., 2007, Współczesne problemy rozwoju ośrodków narciarskich w Polsce - przykład Szczyrku, Prace Geograficzne, 117, pp. 63-77.

PILAWSKI A., 2002, Skrajne formy aktywności fizycznej, [in:] I. Jędrzejczyk (ed.), Rozwój funkcji turystycznej i rekreacyjnej polskich obszarów górskich, Akademia Wychowania Fizycznego w Katowicach, Katowice, pp. 88-93.

RUT J., 2002, Turystyka aktywna w Euroregionie Karpackim. Monografia turystyczna, Wyd. Uniwersytetu Rzeszowskiego, Rzeszów.

SZCZECHOWICZ B., 2006, Funkcjonowanie schronisk turystycznych jako przedsięwzięć komercyjnych, [in:] A. Rapacz (ed.), Gospodarka turystyczna w regionie. Przedsiębiorstwo, samorząd, wspótpraca, Wyd. Akademii Ekonomicznej we Wrocławiu, Jelenia Góra, pp. 134-142.

SZCZECHOWICZ B., 2014, Poziom i zróżnicowanie cen usług noclegowych oferowanych przez schroniska górskie na terenie Karpat Polskich, Słowackich i Czeskich, [in:] J. Kantyka (ed.), Wellness jako forma kultury fizycznej i turystyki - aspekty zdrowotne i ekonomiczne, Wyd. Akademii Wychowania Fizycznego w Katowicach, Katowice, pp. 126-148.

TSUYUZAKI S., 2002, Vegetation development patterns on ski slopes in lowland Hokkaido, northern Japan, Biological Conservation, 108, 2, pp. 239-246.

TÖGLHOFER CH., 2011, From climate variability to weather risk: The impact of snow conditions on tourism demand in Austrian ski areas, doctoral thesis, University of Graz, Graz.

TUPPEN J., 2002, Recent developments in alpine tourism: A life cycle approach, Turyzm, 12, 2, pp. 79-93.

WARSZYŃSKA J., 1995, Geografia turystyczna świata, 1, PWN, Warszawa.

WOLAŃSKA T., 1997, Leksykon - sport dla wszystkich, rekreacja ruchowa, AWF, Warszawa.

ZARZYCKI P., STOSIK A., GROBELNY J., 2006, Specyfika funkcjonowania schronisk górskich $\mathrm{w}$ świetle zmian otoczenia gospodarczego i dynamiki rozwoju sektora turystyki w Polsce, Prace Naukowe Akademii Ekonomicznej we Wroctawiu, 1141, pp. 303-309.

ŻEMŁA M., 2000, Turystyka kwalifikowana w okresie transformacji w Polsce, [in:] L. Żabiński (ed.), Uwarunkowania środowiskowe strategii marketingowych w wybranych sektorach gospodarki, Wyd. Akademii Ekonomicznej w Katowicach, Katowice, pp. 199-234.

ŻEMŁA M., 2014, Foreign tourists on hiking trials in Polish mountains, Geomatics Landmanagement and Landscape, 1, pp. 95-106.

ŻEMŁA M., 2015, Reakcje gestorów schronisk na rezerwacje mailowe w różnych językach. Porównanie obiektów w Polsce, Czechach i Słowacji, Folia Turistica, 36, pp. 125-142.

Article received:

9 January 2018

Accepted:

14 March 2018 